\title{
Effects of body weight and fiber sources on fiber digestibility and short chain fatty acid concentration in growing pigs
}

\author{
Jinbiao Zhao ${ }^{1, a}$, Xuzhou Liu ${ }^{2, a}$, Yi Zhang ${ }^{3}$, Ling Liu', Junjun Wang ${ }^{1}$, and Shuai Zhang ${ }^{1, *}$
}

* Corresponding Author: Shuai Zhang Tel: +86-10-6273-1109, Fax: +86-10-6273-3688,

E-mail: zhangshuai16@cau.edu.cn

'State Key Laboratory of Animal Nutrition, Ministry of Agriculture Feed Industry Centre, China Agricultural University, Beijing 100193, China

${ }^{2}$ Institute of Mycology/Engineering Research Center of Chinese Ministry of Education for Edible and

Medicinal Fungi, Jilin Agricultural University,

Changchun 130118, China

${ }^{3}$ Beijing E-Feed \& E-Vet Cooperation, Beijing 100029, China

a Jinbiao Zhao and Xuzhou Liu contributed equally to this work.

ORCID

Jinbiao Zhao

https://orcid.org/0000-0001-7900-0131

Xuzhou Liu

https://orcid.org/0000-0002-3412-3303

Yi Zhang

https://orcid.org/0000-0001-7110-6767

Ling Liu

https://orcid.org/0000-0002-0761-5185

Junjun Wang

https://orcid.org/0000-0001-9427-3824

Shuai Zhang

https://orcid.org/0000-0001-5435-2640

Submitted Sept 9, 2019; Revised Nov 9, 2019; Accepted Dec 12, 2019
Objective: The study was conducted to determine the effects of body weight (BW) and fiber sources on nutrient digestibility, fiber fermentation and short chain fatty acids (SCFA) concentration in different intestinal segments of growing pigs fed high-fiber diets.

Methods: Nine barrows with initial BW of $25.17 \pm 0.73 \mathrm{~kg}$ and 9 barrows with initial BW of $63.47 \pm 2.18 \mathrm{~kg}$ were allotted to a duplicate $9 \times 2$ Youden Square design with 3 dietary treatments and 2 periods. The dietary treatments were formulated with 3 different high-fiber ingredients: corn bran, sugar beet pulp, and soybean hulls, respectively. Each diet was fed to 3 barrows with different stage of BW in each period.

Results: There were no differences in the apparent ileal digestibility (AID) of most nutrients between pigs at different BW stages. Pigs at $60 \mathrm{~kg}$ had greater $(\mathrm{p}<0.05)$ apparent total tract digestibility (ATTD) of total dietary fiber (TDF), soluble dietary fiber (SDF) and insoluble dietary fiber (IDF), and had greater $(\mathrm{p}<0.05)$ hindgut disappearance of IDF and cellulose than pigs at $25 \mathrm{~kg}$. The acetate, propionate and total SCFA concentrations in ileal digesta and feces of pigs at $60 \mathrm{~kg}$ were greater $(\mathrm{p}<0.05)$ than those of pigs at $25 \mathrm{~kg}$. In addition, fiber sources affected $(\mathrm{p}<0.05)$ the AID of gross energy $(\mathrm{GE})$, organic matter $(\mathrm{OM})$, ether extract (EE), crude protein, SDF and hemicellulose, the hindgut disappearance and ATTD of dietary fiber components, the lactate and propionate concentrations in ileal digesta and the butyrate, valerate and total SCFA concentrations in feces. There were interactions $(\mathrm{p}<0.05)$ between BW and fiber sources on the AID of GE, OM, EE, SDF, hemicellulose, the ATTD of EE, TDF, and IDF, and the hindgut disappearance of SDF and hemicellulose.

Conclusion: Increasing BW mainly improved the digestibility of dietary fiber fractions, and the dietary fiber sources influenced the digestibility of almost all the dietary nutrients in growing pigs.

Keywords: Body Weight; Fiber Sources; Fiber Fermentation; Growing Pig; Short Chain Fatty Acids

\section{INTRODUCTION}

Traditionally, dietary fiber is resistant to the endogenous enzymatic digestion in the small intestine of pigs, but it can be fermented by bacteria in the hindgut of pigs to produce short chain fatty acids (SCFA) [1]. The SCFA is considered to exert a beneficial impact on the gut health of the host [2]. Recently, some studies have reported that dietary fiber fractions could also be fermented in the small intestine of pigs [3,4] because the fiber-degrading bacteria are observed to be present in the stomach and small intestine of pigs. In addition, many studies have demonstrated that the energy and nutrients digestibility in the high-fiber diets was affected by the fiber sources $[5,6]$ due to their different chemical compositions and physical properties. However, there were only a few studies reporting the effect of fiber sources on nutrient digestibility in different digestive sites of pigs $[4,7]$. 
It is also known that the nutrient and energy digestibility of feed ingredients in swine diets could be affected by the body weight (BW) of pigs. The improved apparent total tract digestibility (ATTD) of nutrients and energy in diets was observed with the increased BW when adult sows and growing pigs were compared [8]. Moreover, Huang et al [9] reported that the apparent ileal digestibility (AID) of carbohydrates and the ATTD of dry matter (DM), ash, organic matter (OM), carbohydrates and gross energy (GE) in diets with the inclusion rate of wheat bran were significantly different when fed to growing pigs with different BWs. However, there is little knowledge about the interactive effects of BW and fiber sources on the nutrient digestibility in the small intestine and hindgut of pigs.

Corn bran (CB), sugar beet pulp (SBP), and soybean hulls (SH) are three crop co-products that are commonly used in swine diets, but these ingredients have different chemical compositions and physical characteristics of fiber fractions $[6,10]$. The ingredients of $\mathrm{CB}$ are rich in insoluble fiber fractions and contain a high content of hemicellulose [11], while SBP has more soluble fiber fractions [12]. SH contains a high content of insoluble fiber fractions, and also contains a high content of fermentable oligosaccharides and soluble fiber fractions [13]. No previous studies have focused on the interactive effects of BW and these three fiber sources on nutrient digestibility in different intestinal segments of growing pigs. Therefore, the objective of this study was to investigate effects of BW and fiber sources on fiber components digestibility and SCFA concentration in different intestinal segments of growing pigs fed diets containing $\mathrm{CB}, \mathrm{SBP}$, or $\mathrm{SH}$.

\section{MATERIALS AND METHODS}

The Laboratory Animal Welfare and Animal Experimental Ethical Inspection Committee in China Agricultural University (Beijing, CAU20150925-2) reviewed and approved all protocols used in this study. The animal trial was conducted at the Swine Research Unit of China Agricultural University (Beijing, China).

\section{Animals and housing}

Nine Duroc $\times$ (Landrace $\times$ Yorkshire) barrows with initial BW of $25.17 \pm 0.73 \mathrm{~kg}$ and 9 barrows with initial BW of $63.47 \pm 2.18$ $\mathrm{kg}$ were surgically fitted with a T-cannula in the distal ileum followed the protocol described by Stein et al [14]. Pigs were allowed a 15-day recovery period after surgery and a commercial corn-soybean meal diet was fed during this period. The chemical composition of corn-soybean meal was formulated to meet nutrient requirements for pigs recommended by NRC [15]. All pigs were housed in individual stainlesssteel metabolism crates $(1.4 \mathrm{~m} \times 0.7 \mathrm{~m} \times 0.6 \mathrm{~m})$ equipped with a nipple drinker and a feeder. The room temperature was kept between $20^{\circ} \mathrm{C}$ to $25^{\circ} \mathrm{C}$ throughout the experiment.

\section{Experimental design}

Barrows were allotted to a $9 \times 2$ Youden Square design with 3 dietary treatments and 2 periods, respectively. The dietary treatments included 3 different high-fiber ingredients $(\mathrm{CB}$, $\mathrm{SBP}$, or $\mathrm{SH}$ ), which were the sole fiber source in each treatment diet. Each diet was fed to 3 barrows with different stage of BW in each period. The chemical compositions of $\mathrm{CB}$, SBP, and SH were analyzed and presented in Table 1 . The feed ingredients and analyzed chemical compositions of the three experimental diets are shown in Table 2 and Table 3, respectively. Each experimental diet was randomly assigned

Table 1. The analyzed chemical compositions in corn bran, sugar beet pulp and soybean hulls ( $\mathrm{g} / \mathrm{kg}$, dry matter basis) $)^{11}$

\begin{tabular}{|c|c|c|c|}
\hline Items & Corn bran & $\begin{array}{l}\text { Sugar beet } \\
\text { pulp }\end{array}$ & $\begin{array}{c}\text { Soybean } \\
\text { hulls }\end{array}$ \\
\hline Gross energy (MJ/kg) & 187.9 & 186.8 & 177.1 \\
\hline Crude protein & 161.2 & 114.7 & 220.9 \\
\hline Ash & 27.3 & 29.9 & 68.7 \\
\hline Organic matter & 973.0 & 969.2 & 931.8 \\
\hline Ether extract & 42.8 & 7.2 & 32.5 \\
\hline Neutral detergent fiber & 565.1 & 595.1 & 678.7 \\
\hline Acid detergent fiber & 176.1 & 244.3 & 488.5 \\
\hline Acid detergent lignin & 24.0 & 69.2 & 19.1 \\
\hline Cellulose & 152.2 & 175.1 & 469.4 \\
\hline Hemicellulose & 389.0 & 350.8 & 190.2 \\
\hline Total dietary fiber & 652.6 & 784.1 & 738.8 \\
\hline Soluble dietary fiber & 75.0 & 310.2 & 148.6 \\
\hline Insoluble dietary fiber & 577.6 & 474.0 & 590.1 \\
\hline Calcium & 2.2 & 4.5 & 5.4 \\
\hline Phosphorus & 2.2 & 1.8 & 1.9 \\
\hline \multicolumn{4}{|c|}{ Indispensable amino acids } \\
\hline Arginine & 9.0 & 8.6 & 13.5 \\
\hline Histidine & 5.3 & 3.6 & 5.5 \\
\hline Leucine & 14.5 & 7.1 & 15.3 \\
\hline Isoleucine & 5.9 & 4.3 & 9.0 \\
\hline Lysine & 7.7 & 9.0 & 14.8 \\
\hline Methionine & 2.6 & 5.1 & 3.7 \\
\hline Phenylalanine & 7.3 & 3.8 & 9.4 \\
\hline Threonine & 6.8 & 5.2 & 8.7 \\
\hline Tryptophan & 2.5 & 1.1 & 1.9 \\
\hline Valine & 8.2 & 6.9 & 10.5 \\
\hline \multicolumn{4}{|l|}{ Dispensable amino acids } \\
\hline Alanine & 9.0 & 7.0 & 10.1 \\
\hline Aspartic acid & 12.9 & 11.1 & 23.2 \\
\hline Cystine & 2.9 & 1.3 & 4.4 \\
\hline Glutamic acid & 30.2 & 29.2 & 33.2 \\
\hline Glycine & 7.6 & 5.6 & 12.2 \\
\hline Proline & 14.1 & 12.9 & 11.3 \\
\hline Serine & 8.4 & 6.8 & 11.9 \\
\hline Tyrosine & 3.9 & 5.6 & 5.6 \\
\hline
\end{tabular}

${ }^{1)}$ All data are the results of chemical analysis conducted in duplicate. 
Table 2. The composition ( $\mathrm{g} / \mathrm{kg}$, as-is basis) of the experimental diets

\begin{tabular}{lccc}
\hline \multirow{2}{*}{ Items } & \multicolumn{3}{c}{ Diets } \\
\cline { 2 - 4 } & Corn bran & Sugar beet pulp Soybean hulls \\
\hline Ingredients & & & \\
Corn starch & 446.0 & 444.5 & 425.9 \\
Soy protein isolated & 140.0 & 140.0 & 140.0 \\
Corn bran & 240.0 & - & - \\
Sugar beet pulp & - & 240.0 & - \\
Soybean hulls & - & - & 240.0 \\
Soy oil & 30.0 & 30.0 & 30.0 \\
Sucrose & 100.0 & 100.0 & 120.0 \\
Limestone & 5.5 & - & - \\
Dicalcium phosphate & 16.0 & 22.0 & 21.0 \\
L-lysine- $\mathrm{HCl}$ & 3.5 & 3.5 & 3.2 \\
DL-methionine & 1.0 & 1.5 & 1.4 \\
L-threonine & 1.5 & 2.0 & 2.0 \\
$\mathrm{Cr}_{2} \mathrm{O}_{3}$ & 3.0 & 3.0 & 3.0 \\
$\mathrm{NaCl}$ & 4.5 & 4.5 & 4.5 \\
$\mathrm{~K}_{2} \mathrm{CO}_{3}$ & 3.0 & 3.0 & 3.0 \\
$\mathrm{MgO}$ & 1.0 & 1.0 & 1.0 \\
$\mathrm{Premix}{ }^{1)}$ & 5.0 & 5.0 & 5.0 \\
$\mathrm{Total}$ & 1,000 & 1,000 & 1,000 \\
\hline
\end{tabular}

1) Premix provided the following quantities per kilogram of the complete feed for growing pigs: vitamin $A, 5,512 \mathrm{IU}$; vitamin $\mathrm{D}_{3}, 2,200 \mathrm{IU}$; vitamin $\mathrm{E}, 64 \mathrm{IU}$; vitamin $\mathrm{K}_{3}, 2.2 \mathrm{mg}$; vitamin $\mathrm{B}_{12}, 27.6 \mu \mathrm{g}$; riboflavin, $5.5 \mathrm{mg}$; pantothenic acid, $13.8 \mathrm{mg}$; niacin, $30.3 \mathrm{mg}$; choline chloride, $551 \mathrm{mg}$; $\mathrm{Mn}, 40 \mathrm{mg}(\mathrm{MnO}) ; \mathrm{Fe}, 100 \mathrm{mg}$ (FeS$\left.\mathrm{O}_{4} \cdot \mathrm{H}_{2} \mathrm{O}\right) ; \mathrm{Zn}, 100 \mathrm{mg}(\mathrm{ZnO}) ; \mathrm{Cu}, 100 \mathrm{mg}\left(\mathrm{CuSO}_{4} \cdot 5 \mathrm{H}_{2} \mathrm{O}\right) ; \mathrm{I}, 0.3 \mathrm{mg}\left(\mathrm{Cal}_{2}\right) ; \mathrm{Se}, 0.3 \mathrm{mg}$ $\left(\mathrm{Na}_{2} \mathrm{SeO}_{3}\right)$.

to 3 pigs at each BW stage in each period, and each period lasted for 15 days, including 10 days for diet adaptation, 3 days for fecal collection, and 2 days for digesta collection. Vitamins and minerals were supplied in all diets to meet or exceed the nutrient requirements for pigs recommended by NRC [15]. An amount of $3.0 \mathrm{~g} / \mathrm{kg}$ chromic oxide was included in all diets as an indigestible index.

All pigs had ad libitum access to water, and were fed a daily amount of feed equivalent to $4 \%$ of their initial BW, which were divided into 2 equal meals provided at 0800 and 1600 $\mathrm{h}$. The BW of each pig was recorded at the beginning of the experiment and at the end of each period to calculate the feed allowance.

\section{Sample collection}

Fecal samples were collected on $\mathrm{d} 11$ to $\mathrm{d} 13$ of each period via grab-sampling and stored at $-20^{\circ} \mathrm{C}$. Digesta samples were collected on day 14 and 15 of each period. Collection of ileal digesta was initiated at $0800 \mathrm{~h}$ and ceased at $1800 \mathrm{~h}$ on each collection day into a plastic bag attached to the barrel of the cannula using a cable tie. The bags were removed when filled with digesta and then were stored at $-20^{\circ} \mathrm{C}$ to prevent bacterial degradation of the samples. At the end of each period, digesta and fecal samples were thawed and mixed within pig
Table 3. The analyzed chemical compositions of the experimental diets $(\mathrm{g} / \mathrm{kg}$, as-is basis) ${ }^{11}$

\begin{tabular}{|c|c|c|c|}
\hline \multirow{2}{*}{ Items } & \multicolumn{3}{|c|}{ Diets } \\
\hline & Corn bran & Sugar beet pulp & Soybean hulls \\
\hline Gross energy (MJ/kg) & 16.98 & 16.67 & 16.81 \\
\hline Dry matter & 919.1 & 917.1 & 918.5 \\
\hline Crude protein & 122.3 & 126.2 & 123.4 \\
\hline Ether extract & 16.8 & 9.4 & 14.6 \\
\hline Ash & 39.5 & 44.9 & 44.6 \\
\hline Organic matter & 878.6 & 872.2 & 873.9 \\
\hline Total dietary fiber & 154.9 & 163.3 & 159.7 \\
\hline Soluble dietary fiber & 16.3 & 60.6 & 28.4 \\
\hline Insoluble dietary fiber & 138.6 & 102.7 & 131.3 \\
\hline Neutral detergent fiber & 129.9 & 134.8 & 155.1 \\
\hline Acid detergent fiber & 42.6 & 54.7 & 99.2 \\
\hline Cellulose & 37.1 & 39.8 & 95.0 \\
\hline Hemicellulose & 87.3 & 80.1 & 55.9 \\
\hline \multicolumn{4}{|l|}{ Indispensable amino acids } \\
\hline Arginine & 12.5 & 14.6 & 13.7 \\
\hline Histidine & 3.8 & 4.8 & 5.3 \\
\hline Leucine & 10.9 & 11.7 & 12.7 \\
\hline Isoleucine & 5.9 & 7.4 & 7.5 \\
\hline Lysine & 12.1 & 14.7 & 11.9 \\
\hline Methionine & 4.1 & 3.3 & 4.2 \\
\hline Phenylalanine & 6.3 & 7.1 & 8.6 \\
\hline Threonine & 7.4 & 8.4 & 8.6 \\
\hline Tryptophan & 2.5 & 3.0 & 3.2 \\
\hline Valine & 2.1 & 1.3 & 2.0 \\
\hline \multicolumn{4}{|l|}{ Dispensable amino acids } \\
\hline Alanine & 4.7 & 5.5 & 5.9 \\
\hline Aspartic acid & 13.5 & 17.1 & 18.6 \\
\hline Cystine & 13.5 & 17.2 & 18.8 \\
\hline Glutamic acid & 23.1 & 25.7 & 28.3 \\
\hline Glycine & 5.1 & 6.1 & 7.9 \\
\hline Proline & 11.6 & 12.7 & 11.5 \\
\hline Serine & 5.9 & 7.2 & 8.1 \\
\hline Tyrosine & 3.1 & 3.9 & 4.0 \\
\hline
\end{tabular}

${ }^{1)}$ All data are the results of chemical analysis conducted in duplicate.

and diet. A sub-sample was lyophilized and ground through a 1-mm screen and stored at $-20^{\circ} \mathrm{C}$ prior to chemical analysis. Furthermore, ileal digesta was collected from the cannula directly and fresh fecal sample was collected immediately as soon as feces of pig appeared. Fresh fecal and ileal digesta samples were collected and immediately snap-frozen using liquid nitrogen, and stored at $-80^{\circ} \mathrm{C}$ for the SCFA analysis.

\section{Chemical analyses}

The DM (Method 934.01), crude protein (CP; Method 990.03), ether extract (EE; Method 920.39), ash (Method 942.05), soluble dietary fiber (SDF; Method 991.43), insoluble dietary fiber (IDF; Method 991.43), and chromium (Method 990.08) contents in diets, digesta and feces were determined according to the procedures of the Association of Official 
Analytical Chemists (AOAC) [16]. The OM content was calculated as the difference between DM and ash contents. The total dietary fiber (TDF) content was calculated as the sum of SDF and IDF contents. The neutral detergent fiber (NDF) and acid detergent fiber (ADF) contents were analyzed using fiber bags (Model F57, Ankom Technology, Macedon, NY, USA) and a fiber analyzer $\left(\mathrm{ANKOM}^{200}\right.$ Fiber Analyzer, Ankom Technology, USA) after an adaptation of the procedures described by Van Soest et al [17]. The NDF content was determined using heat stable $a$-amylase and sodium sulphite without correction for insoluble ash. The content of acid detergent lignin (ADL) was also determined following the guidance of Ankom Technology (USA). The hemicellulose content was calculated as the difference between NDF and ADF contents, and the cellulose content was calculated as the difference between $\mathrm{ADF}$ and $\mathrm{ADL}$ contents. The GE in feces, diets and ingredients were measured using an Automatic Isoperibol Oxygen Bomb Calorimeter (Parr 1281 Calorimeter, Moline, IL, USA).

The amino acid (AA; Method 151 982.30) contents in ingredients, diets and digesta were analyzed according to the procedures of AOAC [16]. Specifically, samples were hydrolyzed with $6 \mathrm{~N} \mathrm{HCl}$ at $110^{\circ} \mathrm{C}$ for $24 \mathrm{~h}$ and then analyzed for 15 AA using an Amino Acid Analyzer (Hitachi L-8900, Tokyo, Japan). Methionine and cystine were determined as methionine sulfone and cysteic acid after cold performic acid oxidation overnight and hydrolyzing with $7.5 \mathrm{~N} \mathrm{HCl}$ at $110^{\circ} \mathrm{C}$ for $24 \mathrm{~h}$ using an Amino Acid Analyzer (Hitachi L-8800, Japan). Tryptophan was determined after $\mathrm{LiOH}$ hydrolysis for $22 \mathrm{~h}$ at $110^{\circ} \mathrm{C}$ using HPLC (Agilent 1200 Series, Santa Clara, CA, USA).

The concentrations of lactate and SCFA in ileal digesta and fecal samples were determined using a modified method of Porter and Murray [18]. Specifically, about $1.0 \mathrm{~g}$ sample was diluted with $2.0 \mathrm{~mL}$ of $0.10 \% \mathrm{HCl}$ solution, kept on ice for $30 \mathrm{~min}$, and then centrifuged at $12,000 \mathrm{~g}$ at $0^{\circ} \mathrm{C}$ for $15 \mathrm{~min}$. A $1.0 \mathrm{~mL}$ of the supernatant was passed through a $0.20 \mathrm{~mm}$ Nylon Membrane Filter (Millipore, Bedford, OH, USA) and then $5.0 \mu \mathrm{L}$ of the solution was injected into a gas chromatographic system (Agilent HP 6890 Series, USA).

\section{Calculations}

The AID and ATTD of DM, GE, CP, EE, ADF, NDF, OM, cellulose, hemicellulose, TDF, SDF, IDF, and AA were calculated in all diets using the following equation. The hindgut disappearance of energy and nutrients was calculated as the difference between the AID and ATTD of dietary energy and nutrients.

$$
\mathrm{AD}_{\text {nutrient }}=1-\left(\mathrm{CN}_{\text {digesta or feces }} / \mathrm{DN}_{\text {diet }}\right) \times\left(\mathrm{Cr}_{\text {diel }} / \mathrm{Cr}_{\text {digesta or feces }}\right) \text {, }
$$

where $\mathrm{AD}_{\text {nutrient }}$ is the $\mathrm{AID}$ or ATTD (\%) of dietary energy and nutrients; $\mathrm{CN}_{\text {digesta or feces }}$ is the energy and nutrient levels in ileal digesta or feces $(\mathrm{g} / \mathrm{kg})$; $\mathrm{DN}_{\text {diet }}$ is the energy and nutrient level in diets $(\mathrm{g} / \mathrm{kg})$.

\section{Statistical analysis}

The UNIVARIATE procedure of SAS 9.2 (SAS Inst. Inc., Cary, NC, USA) was used to check the normality of residuals and equal variances. Outliers were identified as any value that deviated from the treatment mean by \pm 3 times of standard deviation. No outliers were observed in this experiment. Data were then analyzed as a $3 \times 2$ factorial treatment arrangement using the GLIMMIX procedure of SAS 9.2. An individual pig was treated as the experimental unit. The statistical model included the fixed main effects of BW, fiber sources, and their interaction effects. Period was also included in the model as a random effect. Statistical differences were separated by Duncan's multiple range test. The significance level was set at $\mathrm{p}<0.05$, whereas $0.05 \leq \mathrm{p}<0.10$ was considered as a tendency.

\section{RESULTS}

All pigs remained healthy and readily consumed their diets. Both feces and digesta samples were successfully collected from all pigs. At the beginning of the animal trial, the average BW of the pigs were $25.17 \pm 0.73 \mathrm{~kg}$ and $63.47 \pm 2.18 \mathrm{~kg}$, and the average BW of the pigs at the end were $41.34 \pm 1.85$ $\mathrm{kg}$ and $74.28 \pm 3.79 \mathrm{~kg}$ at two different growth phases. The information of the pig BW and the treatment allocation are presented in Supplementary Table 1.

\section{Effect of body weight and fiber sources on apparent} ileal digestibility of dietary chemical constituents There were no differences in the AID of dietary GE, DM, ash, EE, TDF, SDF, IDF, NDF, and hemicellulose between pigs at 2 different BW stages (Table 4). Pigs at $60 \mathrm{~kg}$ tended to $(0.05<$ $\mathrm{p}<0.10$ ) have greater AID of dietary OM, ADF, and cellulose compared to those at $25 \mathrm{~kg}$. Pigs fed the $\mathrm{CB}$ diet showed greatest $(\mathrm{p}<0.05)$ AID of GE, DM, OM, EE, and ash but lowest $(p<0.05)$ AID of SDF and hemicellulose compared to those fed the SBP and SH diets. In addition, there were interaction effects $(p<0.05)$ on the AID of GE, OM, EE, SDF, and hemicellulose between BW and fiber sources. Pigs at $60 \mathrm{~kg}$ had greater $(\mathrm{p}<0.05)$ AID of dietary GE, OM, SDF, and hemicellulose when fed the SBP diet, and greater $(\mathrm{p}<0.05)$ AID of dietary GE, OM, and hemicellulose when fed the $\mathrm{SH}$ diet, and lower $(\mathrm{p}<0.05)$ AID of dietary hemicellulose when fed the $\mathrm{CB}$ diet compared with pigs at $25 \mathrm{~kg}$ (Supplementary Table 2). However, the AID of dietary CP and AA, except for glutamic acid, glycine, alanine, valine and proline, were lower $(\mathrm{p}<0.05)$ in pigs at $60 \mathrm{~kg}$ than those in pigs at $25 \mathrm{~kg}$ (Table 5). Moreover, the AID of arginine, histidine, lysine, methionine, and proline in pigs fed the SBP diet were greater $(\mathrm{p}<0.05)$ than 
Table 4. Effects of pig body weight and fiber sources on the apparent ileal digestibility (\%) of dietary nutrients ${ }^{1)}$

\begin{tabular}{|c|c|c|c|c|c|c|c|c|c|}
\hline \multirow{2}{*}{ Items } & \multicolumn{2}{|c|}{ Body weight } & \multicolumn{3}{|c|}{ Diets } & \multirow{2}{*}{ SEM } & \multicolumn{3}{|c|}{$\mathrm{p}$-value } \\
\hline & $60 \mathrm{~kg}$ & $25 \mathrm{~kg}$ & CB & SBP & SH & & Weight & Source & Interaction \\
\hline GE & 72.27 & 71.38 & $73.49^{\mathrm{a}}$ & $71.16^{b}$ & $70.31^{b}$ & 1.37 & 0.432 & 0.029 & 0.023 \\
\hline DM & 69.38 & 67.85 & $71.13^{\mathrm{a}}$ & $67.03^{b}$ & $67.19^{b}$ & 1.25 & 0.154 & $<0.001$ & 0.068 \\
\hline Ash & 17.01 & 19.73 & $24.29^{a}$ & $13.65^{b}$ & $17.17^{\mathrm{ab}}$ & 4.89 & 0.111 & $<0.001$ & 0.314 \\
\hline OM & 72.61 & 70.85 & $73.80^{\mathrm{a}}$ & $71.65^{\mathrm{ab}}$ & $69.74^{b}$ & 1.11 & 0.064 & $<0.001$ & $<0.001$ \\
\hline $\mathrm{EE}$ & 79.26 & 73.67 & $78.89^{\mathrm{a}}$ & $68.59^{b}$ & $71.92^{\mathrm{ab}}$ & 6.37 & 0.293 & 0.014 & $<0.001$ \\
\hline TDF & 8.92 & 8.41 & 2.09 & 15.84 & 8.05 & 5.52 & 0.663 & 0.094 & 0.323 \\
\hline SDF & 27.85 & 22.67 & $9.68^{c}$ & $21.86^{b}$ & $44.25^{\mathrm{a}}$ & 9.81 & 0.529 & $<0.001$ & $<0.001$ \\
\hline IDF & 2.66 & 3.00 & 1.74 & 5.18 & 1.57 & 4.34 & 0.809 & 0.723 & 0.193 \\
\hline NDF & 14.95 & 15.97 & 15.01 & 17.72 & 13.64 & 3.72 & 0.740 & 0.552 & 0.068 \\
\hline ADF & 4.51 & 4.31 & 4.40 & 6.08 & 2.75 & 4.27 & 0.073 & 0.188 & 0.894 \\
\hline Cellulose & 3.85 & 5.75 & 4.51 & 7.21 & 2.68 & 4.27 & 0.064 & 0.091 & 0.872 \\
\hline Hemicellulose & 34.66 & 30.06 & $19.10^{b}$ & $38.94^{\mathrm{a}}$ & $39.03^{\mathrm{a}}$ & 4.37 & 0.210 & $<0.001$ & 0.014 \\
\hline
\end{tabular}

1) Data represent least square means $(n=6)$, and individual pig was treated as the experimental unit.

CB, corn bran; SBP, sugar beet pulp; SH, soybean hulls; SEM, standard error of the mean; GE, gross energy; DM, dry matter; OM, organic matter; EE, ether extract; TDF, total dietary fiber; SDF, soluble dietary fiber; IDF, insoluble dietary fiber; NDF, neutral detergent fiber; ADF, acid detergent fiber.

${ }^{a-c}$ Means with different superscript in the same row of body weight or diets are significantly different.

those in pigs fed the $\mathrm{CB}$ and $\mathrm{SH}$ diets. There were also interaction effects on the AID of dietary CP and most AA between BW and fiber sources, except for histidine, leucine, alanine, cystine, glutamic acid, glycine, and proline.

\section{Effect of body weight and fiber sources on apparent}

total tract digestibility of dietary chemical constituents Pigs at $60 \mathrm{~kg}$ had greater $(\mathrm{p}<0.05)$ ATTD of dietary TDF, SDF, and IDF compared with pigs at $25 \mathrm{~kg}$ (Table 6). In addition, pigs fed the CB diet showed lower $(\mathrm{p}<0.05)$ ATTD of all dietary nutrients, except for $\mathrm{EE}$ and ash compared with pigs fed the SBP and SH diets. There were interaction effects $(\mathrm{p}<0.05)$

Table 5. Effects of pig body weight and fiber sources on the apparent ileal digestibility coefficient of amino acids ${ }^{1)}$

\begin{tabular}{|c|c|c|c|c|c|c|c|c|c|}
\hline \multirow{2}{*}{ Items } & \multicolumn{2}{|c|}{ Body weight } & \multicolumn{3}{|c|}{ Diets } & \multirow{2}{*}{ SEM } & \multicolumn{3}{|c|}{$\mathrm{p}$-value } \\
\hline & $60 \mathrm{~kg}$ & $25 \mathrm{~kg}$ & CB & SBP & SH & & Weight & Source & Interaction \\
\hline $\begin{array}{l}\text { Crude protein } \\
\text { Indispensable amino acids }\end{array}$ & $83.02^{B}$ & $86.19^{A}$ & $83.52^{b}$ & $84.25^{\mathrm{ab}}$ & $86.05^{a}$ & 2.01 & $<0.001$ & 0.022 & $<0.001$ \\
\hline Arginine & $86.32^{B}$ & $92.00^{A}$ & $89.53^{\mathrm{ab}}$ & $90.14^{\mathrm{a}}$ & $87.80^{b}$ & 2.4 & $<0.001$ & $<0.001$ & 0.030 \\
\hline Histidine & $83.44^{B}$ & $89.31^{\mathrm{A}}$ & $85.04^{b}$ & $87.70^{\mathrm{a}}$ & $86.38^{\mathrm{ab}}$ & 1.54 & $<0.001$ & 0.041 & 0.374 \\
\hline Isoleucine & $84.96^{B}$ & $90.83^{\mathrm{A}}$ & 86.95 & 88.44 & 88.29 & 1.32 & $<0.001$ & 0.064 & 0.028 \\
\hline Leucine & $84.22^{B}$ & $89.12^{A}$ & 85.53 & 87.80 & 86.69 & 1.26 & 0.023 & 0.079 & 0.174 \\
\hline Lysine & $86.73^{B}$ & $92.08^{\mathrm{A}}$ & $87.67^{b}$ & $91.81^{\mathrm{a}}$ & $88.73^{\mathrm{ab}}$ & 1.09 & $<0.001$ & $<0.001$ & $<0.001$ \\
\hline Methionine & $74.86^{B}$ & $78.74^{\mathrm{A}}$ & $71.08^{b}$ & $86.31^{\mathrm{a}}$ & $73.01^{b}$ & 2.46 & $<0.001$ & $<0.001$ & $<0.001$ \\
\hline Phenylalanine & $85.65^{\mathrm{B}}$ & $89.87^{\mathrm{A}}$ & 86.78 & 88.00 & 88.50 & 1.31 & $<0.001$ & 0.059 & 0.042 \\
\hline Threonine & $78.34^{B}$ & $88.34^{\mathrm{A}}$ & 82.74 & 83.36 & 83.91 & 1.15 & $<0.001$ & 0.073 & 0.014 \\
\hline Valine & 87.21 & 83.80 & 85.90 & 85.53 & 85.10 & 1.15 & 0.154 & 0.611 & 0.020 \\
\hline Dispensable amino acids & & & & & & & & & \\
\hline Alanine & 86.20 & 86.31 & 83.59 & 89.21 & 85.96 & 3.74 & 0.932 & 0.157 & 0.271 \\
\hline Aspartic acid & $84.46^{\mathrm{B}}$ & $90.11^{\mathrm{A}}$ & 86.58 & 88.26 & 87.02 & 1.27 & $<0.001$ & 0.063 & $<0.001$ \\
\hline Cystine & $76.68^{B}$ & $88.66^{A}$ & $80.57^{b}$ & $82.80^{\mathrm{ab}}$ & $84.64^{a}$ & 1.67 & $<0.001$ & $<0.001$ & 0.133 \\
\hline Glutamic acid & 88.70 & 92.47 & 90.52 & 90.96 & 90.28 & 1.92 & 0.324 & 0.133 & 0.112 \\
\hline Glycine & 83.40 & 83.19 & 87.76 & 78.52 & 83.59 & 5.98 & 0.910 & 0.240 & 0.758 \\
\hline Proline & 69.09 & 64.15 & $68.27^{\mathrm{ab}}$ & $77.37^{\mathrm{a}}$ & $54.22^{b}$ & 8.25 & 0.667 & 0.031 & 0.143 \\
\hline Serine & $76.37^{B}$ & $86.75^{\mathrm{A}}$ & 81.75 & 82.80 & 80.12 & 1.36 & $<0.001$ & 0.109 & $<0.001$ \\
\hline Tyrosine & $80.40^{B}$ & $82.50^{A}$ & $80.26^{b}$ & $80.50^{b}$ & $83.59^{a}$ & 1.60 & $<0.001$ & 0.024 & $<0.001$ \\
\hline
\end{tabular}

1) Data represent least square means $(n=6)$, and individual pig was treated as the experimental unit.

CB, corn bran; SBP, sugar beet pulp; SH, soybean hulls; SEM, standard error of the mean.

$A, B, a, b$ Means with different superscript in the same row of body weight or diets are significantly different. 
Table 6. Effects of pig body weight and fiber sources on the apparent total tract digestibility (\%) of dietary nutrients ${ }^{1)}$

\begin{tabular}{|c|c|c|c|c|c|c|c|c|c|}
\hline \multirow{2}{*}{ Items } & \multicolumn{2}{|c|}{ Body weight } & \multicolumn{3}{|c|}{ Diets } & \multirow{2}{*}{ SEM } & \multicolumn{3}{|c|}{$\mathrm{p}$-value } \\
\hline & $60 \mathrm{~kg}$ & $25 \mathrm{~kg}$ & CB & SBP & SH & & Weight & Source & Interaction \\
\hline GE & 86.64 & 85.95 & $82.69^{c}$ & $89.50^{a}$ & $86.69^{b}$ & 0.72 & 0.263 & $<0.001$ & 0.421 \\
\hline DM & 86.04 & 85.31 & $81.90^{c}$ & $88.99^{\mathrm{a}}$ & $86.14^{b}$ & 0.76 & 0.242 & $<0.001$ & 0.294 \\
\hline Ash & $45.47^{\mathrm{B}}$ & $50.62^{A}$ & $49.41^{\mathrm{a}}$ & $42.85^{b}$ & $51.88^{\mathrm{a}}$ & 2.42 & 0.020 & $<0.001$ & 0.058 \\
\hline OM & 88.04 & 87.13 & $83.38^{c}$ & $91.49^{\mathrm{a}}$ & $87.90^{b}$ & 0.69 & 0.121 & $<0.001$ & 0.410 \\
\hline $\mathrm{EE}$ & 43.19 & 36.01 & $46.71^{\mathrm{a}}$ & $32.78^{b}$ & $39.30^{b}$ & 4.76 & 0.079 & $<0.001$ & $<0.001$ \\
\hline TDF & $58.39^{A}$ & $51.21^{B}$ & $33.22^{b}$ & $69.21^{\mathrm{a}}$ & $67.97^{\mathrm{a}}$ & 7.22 & 0.037 & $<0.001$ & $<0.001$ \\
\hline SDF & $82.74^{\mathrm{A}}$ & $74.62^{B}$ & $58.27^{b}$ & $90.13^{\mathrm{a}}$ & $87.64^{a}$ & 9.63 & $<0.001$ & $<0.001$ & 0.334 \\
\hline IDF & $52.99^{A}$ & $47.11^{B}$ & $28.92^{b}$ & $57.53^{\mathrm{a}}$ & $63.69^{\mathrm{a}}$ & 8.15 & 0.020 & $<0.001$ & $<0.001$ \\
\hline NDF & 58.22 & 60.03 & $40.17^{b}$ & $70.28^{\mathrm{a}}$ & $66.92^{\mathrm{a}}$ & 2.96 & 0.463 & $<0.001$ & 0.211 \\
\hline ADF & 51.95 & 50.87 & $30.39^{b}$ & $64.80^{\mathrm{a}}$ & $59.05^{a}$ & 3.82 & 0.732 & $<0.001$ & 0.510 \\
\hline Cellulose & 59.87 & 56.94 & $33.14^{c}$ & $80.57^{\mathrm{a}}$ & $61.49^{b}$ & 4.06 & 0.390 & $<0.001$ & 0.592 \\
\hline Hemicellulose & 68.09 & 67.56 & $43.13^{b}$ & $75.81^{\mathrm{a}}$ & $77.03^{\mathrm{a}}$ & 2.53 & 0.871 & $<0.001$ & 0.384 \\
\hline
\end{tabular}

1) Data represent least square means $(n=6)$, and individual pig was treated as the experimental unit.

CB, corn bran; SBP, sugar beet pulp; SH, soybean hulls; SEM, standard error of the mean; GE, gross energy; DM, dry matter; OM, organic matter; EE, ether extract; TDF, total dietary fiber; SDF, soluble dietary fiber; IDF, insoluble dietary fiber; NDF, neutral detergent fiber; ADF, acid detergent fiber.

$A, B, a-c$ Means with different superscript in the same row of body weight or diets are significantly different.

on the ATTD of dietary EE, TDF, and IDF between BW and fiber sources. Pigs at $60 \mathrm{~kg}$ showed greater ATTD of TDF and IDF in SBP and SH diets compared with those at $25 \mathrm{~kg}$, but BW did not affect the AID of fiber components when pigs were fed the CB diet (data not shown).

\section{Effect of body weight and fiber sources on hindgut} disappearance of dietary chemical constituents Pigs at $60 \mathrm{~kg}$ had greater $(\mathrm{p}<0.05)$ hindgut disappearance of dietary IDF and cellulose compared with pigs at $25 \mathrm{~kg}$ (Table 7). The hindgut disappearance of dietary GE, DM, OM, TDF, IDF, NDF, ADF, cellulose and hemicellulose in pigs fed the CB diet were lower $(p<0.05)$ than those in pigs fed the SBP and SH diets. There were interaction effects $(\mathrm{p}<0.05)$ on the hindgut disappearance of SDF and hemicellulose between BW and fiber sources.

\section{Effect of body weight and fiber sources on SCFA concentrations in ileal digesta and feces of pigs}

Pigs at $60 \mathrm{~kg}$ had greater $(\mathrm{p}<0.05)$ concentrations of lactate, acetate, propionate and total SCFA in the ileal digesta, and greater $(\mathrm{p}<0.05)$ concentrations of acetate, propionate, butyrate, valerate and total SCFA in feces compared with pigs at $25 \mathrm{~kg}$ (Table 8). The lactate concentration in ileal digesta of pigs fed the CB diet was greater $(\mathrm{p}<0.05)$ than that of pigs fed the SBP diets, while the butyrate, valerate and total SCFA

Table 7. Effects of pig body weight and fiber sources on the hindgut disappearance (\%) of dietary nutrients ${ }^{11}$

\begin{tabular}{|c|c|c|c|c|c|c|c|c|c|}
\hline \multirow{2}{*}{ Items } & \multicolumn{2}{|c|}{ Body weight } & \multicolumn{3}{|c|}{ Diets } & \multirow{2}{*}{ SEM } & \multicolumn{3}{|c|}{$\mathrm{p}$-value } \\
\hline & $60 \mathrm{~kg}$ & $25 \mathrm{~kg}$ & CB & SBP & SH & & Weight & Source & Interaction \\
\hline GE & 14.37 & 14.58 & $8.70^{b}$ & $18.34^{\mathrm{a}}$ & $16.38^{\mathrm{a}}$ & 1.61 & 0.881 & $<0.001$ & 0.164 \\
\hline DM & 16.66 & 17.46 & $10.27^{c}$ & $21.96^{\mathrm{a}}$ & $18.96^{b}$ & 1.43 & 0.504 & $<0.001$ & 0.203 \\
\hline Ash & 28.46 & 30.89 & 25.12 & 29.21 & 34.71 & 5.61 & 0.742 & 0.122 & 0.520 \\
\hline $\mathrm{OM}$ & 15.43 & 16.28 & $9.59^{b}$ & $19.83^{\mathrm{a}}$ & $18.15^{\mathrm{a}}$ & 1.25 & 0.420 & $<0.001$ & 0.087 \\
\hline $\mathrm{EE}$ & -50.27 & -37.66 & -32.18 & -57.10 & -32.62 & 7.83 & 0.133 & 0.064 & 0.231 \\
\hline TDF & 49.47 & 42.81 & $31.13 b$ & $53.37^{\mathrm{a}}$ & $59.92^{\mathrm{a}}$ & 6.54 & 0.062 & $<0.001$ & 0.063 \\
\hline SDF & 54.88 & 51.94 & 48.59 & 68.26 & 43.39 & 8.81 & 0.231 & 0.312 & $<0.001$ \\
\hline IDF & $50.33^{A}$ & $44.12^{B}$ & $27.19^{b}$ & $52.36^{\mathrm{a}}$ & $62.12^{\mathrm{a}}$ & 5.9 & 0.012 & $<0.001$ & 0.222 \\
\hline NDF & 43.26 & 44.06 & $25.15^{b}$ & $52.56^{\mathrm{a}}$ & $53.28^{\mathrm{a}}$ & 4.29 & 0.819 & $<0.001$ & 0.448 \\
\hline$A D F$ & 47.45 & 46.56 & $25.99^{b}$ & $58.72^{a}$ & $56.30^{\mathrm{a}}$ & 5.58 & 0.110 & $<0.001$ & 0.842 \\
\hline Cellulose & $56.02^{A}$ & $51.19^{B}$ & $28.64^{c}$ & $73.36^{\mathrm{a}}$ & $58.81^{b}$ & 5.72 & 0.041 & $<0.001$ & 0.664 \\
\hline Hemicellulose & 33.43 & 37.50 & $24.03^{b}$ & $36.86^{a}$ & $38.00^{\mathrm{a}}$ & 4.19 & 0.806 & $<0.001$ & 0.041 \\
\hline
\end{tabular}

1) Data represent least square means $(n=6)$, and individual pig was treated as the experimental unit.

CB, corn bran; SBP, sugar beet pulp; SH, soybean hulls; SEM, standard error of the mean; GE, gross energy; DM, dry matter; OM, organic matter; EE, ether extract; TDF, total dietary fiber; SDF, soluble dietary fiber; IDF, insoluble dietary fiber; NDF, neutral detergent fiber; ADF, acid detergent fiber.

$A, B, a-c$ Means with different superscript in the same row of body weight or diets are significantly different. 
Table 8. Effects of pig body weight and fiber sources on short chain fatty acids $(\mathrm{mg} / \mathrm{g})$ concentration in the fresh ileal digesta and feces of pigs"

\begin{tabular}{|c|c|c|c|c|c|c|c|c|c|}
\hline \multirow{2}{*}{ Items (mg/g) } & \multicolumn{2}{|c|}{ Body weight } & \multicolumn{3}{|c|}{ Diets } & \multirow{2}{*}{ SEM } & \multicolumn{3}{|c|}{$\mathrm{p}$-value } \\
\hline & $60 \mathrm{~kg}$ & $25 \mathrm{~kg}$ & $C B$ & SBP & SH & & Weight & Source & Interaction \\
\hline \multicolumn{10}{|l|}{ Feces } \\
\hline Lactate & 0.23 & 0.62 & 0.33 & 0.41 & 0.55 & 0.07 & 0.152 & 0.194 & 0.274 \\
\hline Acetate & $10.32^{A}$ & $8.91^{B}$ & 8.06 & 9.52 & 11.27 & 0.93 & 0.011 & 0.152 & 0.322 \\
\hline Propionate & $6.69^{A}$ & $4.84^{B}$ & 4.65 & 4.27 & 8.38 & 0.71 & 0.013 & 0.111 & 0.257 \\
\hline Isobutyrate & 0.66 & 0.36 & 0.37 & 0.78 & 0.36 & 0.16 & 0.718 & 0.310 & 0.658 \\
\hline Butyrate & $4.01^{\mathrm{A}}$ & $2.95^{\mathrm{B}}$ & $2.17^{c}$ & $3.31^{\mathrm{b}}$ & $4.96^{\mathrm{a}}$ & 0.46 & 0.014 & 0.008 & 0.082 \\
\hline Isovalerate & 1.52 & 0.76 & 0.54 & 0.99 & 1.89 & 0.19 & 0.653 & 0.124 & 0.464 \\
\hline Valerate & $1.47^{\mathrm{A}}$ & $1.07^{\mathrm{B}}$ & $0.49^{\mathrm{b}}$ & $0.96^{b}$ & $2.36^{\mathrm{a}}$ & 0.21 & 0.008 & 0.012 & 0.023 \\
\hline Total SCFAs & $24.91^{\mathrm{A}}$ & $19.74^{B}$ & $16.80^{c}$ & $20.35^{b}$ & $29.83^{\mathrm{a}}$ & 1.29 & 0.006 & 0.011 & 0.241 \\
\hline \multicolumn{10}{|l|}{ |leal digesta } \\
\hline Lactate & $3.45^{\mathrm{A}}$ & $2.41^{B}$ & $3.77^{\mathrm{a}}$ & $2.11^{\mathrm{b}}$ & $2.90^{\mathrm{ab}}$ & 0.93 & 0.031 & 0.014 & 0.391 \\
\hline Acetate & $5.87^{\mathrm{A}}$ & $2.83^{B}$ & 3.88 & 4.35 & 4.83 & 0.51 & 0.012 & 0.653 & 0.245 \\
\hline Propionate & $1.08^{\mathrm{A}}$ & $0.92^{B}$ & $0.60^{b}$ & $0.81^{b}$ & $1.60^{\mathrm{a}}$ & 0.21 & 0.010 & 0.011 & 0.122 \\
\hline Isobutyrate & 0.00 & 0.00 & 0.00 & 0.00 & 0.11 & 0.05 & 0.884 & 0.402 & 0.893 \\
\hline Butyrate & 0.25 & 0.17 & 0.23 & 0.21 & 0.20 & 0.09 & 0.716 & 0.560 & 0.786 \\
\hline Total SCFAs & $11.55^{\mathrm{A}}$ & $6.54^{B}$ & 9.25 & 8.07 & 9.82 & 1.21 & 0.008 & 0.132 & 0.354 \\
\hline
\end{tabular}

1) Data represent least square means $(n=6)$, and individual pig was treated as the experimental unit.

CB, corn bran; SBP, sugar beet pulp; SH, soybean hulls; SEM, standard error of the mean; SCFAs, short chain fatty acids.

Isobutyrate, isovalerate and valerate in the ileal digesta were not determined.

$A, B, a-c$ Means with different superscript in the same row of body weight or diets are significantly different.

contents in feces of pigs fed the SH diet was higher $(\mathrm{p}<0.05)$ than those pigs fed the CB and SBP diets. Furthermore, there were no interaction effects on SCFA concentrations, except for the fecal valerate content, between BW and fiber sources.

\section{DISCUSSION}

Interactive effects on fiber digestibility between body weight and fiber sources

In the present study, there were some interactions on the AID of GE, OM, SDF, hemicellulose and the ATTD of TDF and IDF between BW and dietary fiber sources. Pigs with greater BW showed increased AID of GE, DM, OM, SDF and hemicellulose when fed the SBP and SH diets, but BW did not affect the nutrient digestibility when the $\mathrm{CB}$ diet was fed. The different effects of BW on the AID of SDF and hemicellulose may be associated with the more fermentable non-starch polysaccharides in SBP and SH, such as pectins [19], resulting in greater AID of dietary GE and OM. Similarly, increased BW of pigs improved the ATTD of TDF and IDF in the SBP and SH diets, but had no positive effects on the ATTD of dietary fiber in the CB diet. Those results indicated that the effects of BW on dietary nutrient digestibility were affected by fiber sources.

Effect of fiber sources on fiber digestibility and SCFA concentration in different digestive sites of pigs In the present study, the AID of dietary GE and DM for pigs fed the CB diet were greater than those fed the SBP and SH diets. The higher AID of GE and OM in CB diet was mainly caused by a greater $\mathrm{EE}$ digestibility, which is relative to amounts of $\mathrm{EE}$ in $\mathrm{CB}$ caused by processing technology. The AID of dietary SDF and hemicellulose in CB diet were lower compared with those in $\mathrm{SH}$ and SBP diets in this study, which may be caused by more fermentable SDF contents in SBP and $\mathrm{SH}$ diets. The above contradiction between greater energy digestibility and lower SDF digestibility in the CB diet could be explained by the small proportion of SDF in $\mathrm{CB}$, resulting in a lower contribution of SDF digestibility to the energy utilization efficiency. In addition, the AID of dietary $\mathrm{CP}$ and most AA were affected by the dietary fiber sources. A possible explanation for the low AA digestibility in the $\mathrm{CB}$ diet was that IDF in $\mathrm{CB}$ increased the evacuation rate and decreased the retention time of digesta in the gut. Besides, another possible reason for the effect of different fiber sources on AA digestibility was the difference in endogenous nitrogen losses in pig intestine [20].

In this study, the ATTD of dietary GE, DM, OM, TDF, SDF, IDF, NDF, ADF, cellulose, and hemicellulose in pigs fed the SBP and SH diets were greater than those fed the CB diet, which was in accordance with the results from Chabeauti et al [21], who reported the ATTD of non-starch polysaccharides in growing pigs to be $16.3 \%$ for wheat straw, $43.5 \%$ for wheat bran, $69.5 \%$ for SBP, and $79.1 \%$ for SH. The lower ATTD of nutrients in CB diet may be caused by its high IDF content, which is difficult to be fermented by gut bacteria and could speed up the evacuation rate of digesta in the gut of pigs [12]. Moreover, the ATTD of dietary EE in pigs fed 
the $\mathrm{CB}$ diet was greater than those fed the $\mathrm{SBP}$ and $\mathrm{SH}$ diets, which may be caused by the high endogenous losses of $\mathrm{EE}$ in SBP and SH groups, resulting from dietary fiber fermentation to produce SCFA.

In the present study, there were differences in the hindgut disappearance of all dietary nutrients we tested, except for EE and SDF, among pigs fed the CB, SBP, and SH diets. The result was associated with the greater SDF concentration in SBP and SH diets and its higher fermentation ability in pigs. The result of negative values for the hindgut disappearance of dietary EE was consistent with the previous study [22], which is most likely a consequence of fatty acids synthesis in the hindgut, because the presence of carbohydrates in the hindgut allows microbes to synthesize fatty acids.

Pigs fed the CB diet had greater lactate concentration in the ileal digesta, but lower content of butyrate, valerate and total SCFA in the feces compared with those fed the SBP and $\mathrm{SH}$ diets. The lower concentration of SCFA in the CB treatment may be caused by the high IDF content in $\mathrm{CB}$, which is consistent with the results of lower fiber fermentation in $\mathrm{CB}$ diet. On the other hand, SBP and SH are rich in SDF fraction that could be largely fermented to produce SCFA in the hindgut of pigs. However, pigs fed the SBP diet demonstrated lower nutrient digestibility compared to those fed the $\mathrm{SH}$ diet, while SBP had greater proportion of SDF compared to SH, which could be ascribed to the higher lignin content in SBP that is difficult to be fermented by gut microbiota. Moreover, the present study showed that pigs fed the SH diet had the greatest SCFA concentration in the feces, which was consistent with the results reported by Freire et al. [23], who compared the effects of the inclusion rate of $20 \%$ wheat bran, SBP, SH, and alfalfa meal on total SCFA concentration in the cecum of weanling pigs, and found that dietary $\mathrm{SH}$ inclusion increased the total SCFA concentrations by $11.2 \%$, $30.5 \%$, and $27.2 \%$ as compared with diets containing wheat bran, SBP and alfalfa meal, respectively.

\section{Effects of body weight on fiber digestibility and SCFA concentration in different digestive sites of pigs}

There were no differences in the AID of dietary nutrients between pigs at $60 \mathrm{~kg}$ and pigs at $25 \mathrm{~kg}$ in our study. These results were consistent with the previous study, which reported that AID of most nutrients and energy in high-fiber diets with wheat bran supplementation were not affected by BW except for carbohydrates [9]. The explanation for the previous result was that the small intestine is relatively fully developed at 20 $\mathrm{kg}$, while the large intestine keeps developing until $150 \mathrm{~kg}$ in pigs. Although there were no significant differences in the apparent nutrient digestibility in pigs at different BW, an increased SCFA concentration in the ileal digesta of pigs at 60 $\mathrm{kg}$ was observed, which may be associated with the trend of improved AID of dietary ADF and cellulose [24]. However, a study showed greater capacity of sows to digest fibrous components compared to growing pigs, and it was shown that sows could degrade a larger part of the dietary fiber in the small intestine than growing pigs [25]. These difference in the energy and nutrient digestibility with different BWs depends on the dietary fiber sources, which was demonstrated by our results through the interaction effects on some nutrient digestibility between BW and fiber sources. Furthermore, pigs at $60 \mathrm{~kg}$ had significantly lower AID of dietary CP and most AA compared with pigs at $25 \mathrm{~kg}$ in the present study, which was consistent with the previous report that the AID of CP and AA was significantly influenced by BW with in general around 1\%-unit higher at low BW [26].

Pigs at $60 \mathrm{~kg}$ also had greater ATTD and hindgut disappearance of dietary TDF, IDF, and cellulose compared with pigs at $25 \mathrm{~kg}$ in the current study, resulting in the improved SCFA concentration in the feces. Huang et al [9] reported that the ATTD of DM, ash, OM, carbohydrates and GE in diets with wheat bran supplementation were significantly different when fed to pigs at different stages of BW. The ATTD of nutrients and energy in diets are improved with increased BW when adult sows and growing pigs are compared [8]. For weaned pigs, increased BW of pigs improved the ATTD of all dietary components except for NDF compared to pigs at three weeks post-weaning [27]. The main reason for the results that heavier pigs showed greater ileal digestibility of chemical components is that pigs with heavier BW have more developed and larger gastro-intestinal tract, slower digesta transit time, higher cellulolytic activity and increased fermentation capacity of microflora [28]. However, Le Goff and Noblet [29] reported that the apparent in vivo digestibility of dietary energy and most nutrients increased with BW of pigs, but they indicated that the greater capacity of heavy pigs or adult sows to digest dietary fiber is not due to an increased intrinsic ability of the microbial flora to degrade dietary fiber.

A previous study also showed that sows have a higher capacity to digest insoluble non-starch polysaccharides, whereas no difference in the digestibility of soluble non-starch polysaccharides was found between growing pigs and sows [30], which was consistent with the result in the present study. It may be caused by the high fermentable ability of dietary SDF in the small intestine of pigs. Overall, the BW of pig could affect the digestibility of dietary chemical constituents, especially nutrients digestibility in the hindgut of pig.

\section{CONCLUSION}

High-fiber ingredients with different physicochemical properties had different effects on energy and nutrients digestibility, and SCFA concentration in the foregut and hindgut of pigs. The effect of pig BW on dietary energy and nutrients digest- 
ibility was influenced by dietary fiber sources. Therefore, it is necessary to take the dietary fiber sources into consideration when formulating diets for pigs at different growing stages.

\section{CONFLICT OF INTEREST}

We certify that there is no conflict of interest with any financial organization regarding the material discussed in the manuscript. Zhang Y is an employee of E-Feed \& E-Vet Cooperation.

\section{ACKNOWLEDGMENTS}

This research was supported by the Chinese Universities Scientific Fund (No. 2019TC120), the National Natural Science Foundation of China (No. 31702121), and the 111 Project (No. B16044).

\section{REFERENCES}

1. Williams BA, Verstegen MWA, Tamminga S. Fermentation in the large intestine of single-stomached animals and its relationship to animal health. Nutr Res Rev 2001;14:207-28. https://doi.org/10.1079/NRR200127

2. Koh A, De Vadder F, Kovatcheva-Datchary P, Backhed F. From dietary fiber to host physiology: short-chain fatty acids as key bacterial metabolites. Cell 2016;165:1332-45. https:// doi.org/10.1016/j.cell.2016.05.041

3. Jha R, Leterme P. Feed ingredients differing in fermentable fibre and indigestible protein content affect fermentation metabolites and faecal nitrogen excretion in growing pigs. Animal 2012;6:603-11. https://doi.org/10.1017/S17517311 11001844

4. Lærke HN, Arent S, Dalsgaard S, Bach Knudsen KE. Effect of xylanases on ileal viscosity, intestinal fiber modification, and apparent ileal fiber and nutrient digestibility of rye and wheat in growing pigs. J Anim Sci 2015;93:4323-35. https:// doi.org/10.2527/jas.2015-9096

5. Urriola PE, Stein HH. Effects of distillers dried grains with solubles on amino acid, energy, and fiber digestibility and on hindgut fermentation of dietary fiber in a corn-soybean meal diet fed to growing pigs. J Anim Sci 2010;88:1454-62. https://doi.org/10.2527/jas.2009-2162

6. Choi H, Sung JY, Kim BG. Neutral detergent fiber rather than other dietary fiber types as an independent variable increases the accuracy of prediction equation for digestible energy in feeds for growing pigs. Asian-Australas J Anim Sci 2020;33: 615-22. https://doi.org/10.5713/ajas.19.0103

7. Jaworski NW, Stein HH. Disappearance of nutrients and energy in the stomach and small intestine, cecum, and colon of pigs fed corn-soybean meal diets containing distillers dried grains with solubles, wheat middlings, or soybean hulls. J Anim Sci 2017;95:727-39. https://doi.org/10.2527/jas.2016.
0752

8. Etienne M, Noblet J, Dourmad JY, Castaing J. Digestive utilization of feeds in lactating sows. Comparison with growing pigs. In: Laplace JP, Février C, Barbeau A, editors. Digestive physiology in pigs. St. Malo, France; EAAP; 1997. No. 88, p. 583-6.

9. Huang Q, Su YB, Li DF, et al. Effects of inclusion levels of wheat bran and body weight on ileal and fecal digestibility in growing pigs. Asian-Australas J Anim Sci 2015;28:84754. https://doi.org/10.5713/ajas.14.0769

10.Högberg A, Lindberg JE. The effect of level and type of cereal non-starch polysaccharides on the performance, nutrient utilization and gut environment of pigs around weaning. Anim Feed Sci Technol 2006;127:200-19. https://doi.org/10. 1016/j.anifeedsci.2005.09.004

11. Carneiro M, Lordelo M, Cunha LF, Freire J. Microbial activity in the gut of piglets: II. Effect of fibre source and enzyme supplementation. Livest Sci 2007;108:262-5. https://doi.org/ 10.1016/j.livsci.2007.01.069

12. Molist F, Gómez de Segura A, Gasa J, et al. Effects of the insoluble and soluble dietary fibre on the physicochemical properties of digesta and the microbial activity in early weaned piglets. Anim Feed Sci Technol 2009;149:346-53. https://doi. org/10.1016/j.anifeedsci.2008.06.015

13. Rooke JA, Slessor M, Fraser H, Thomson JR. Growth performance and gut function of piglets weaned at four weeks of age and fed protease-treated soya-bean meal. Anim Feed Sci Technol 1998;70:175-90. https://doi.org/10.1016/S03778401(97)00083-7

14. Stein HH, Shipley CF, Easter RA. Technical note: A technique for inserting a T-cannula into the distal ileum of pregnant sows. J Anim Sci 1998;76:1433-6. https://doi.org/10.2527/ 1998.7651433x

15. Committee on Nutrient Requirements of Swine, National Research Council. Nutrient requirements of swine. 11th ed. Washington, DC, USA: National Academy Press; 2012.

16. Latimer GW. AOAC International. Official methods of analysis of AOAC International. 19th ed. Gaithersburg, MD, USA: AOAC International; 2012.

17. Van Soest PJ, Robertson JB, Lewis BA. Methods for dietary fiber, neutral detergent fiber, and non-starch polysaccharides in relation to animal nutrition. J Dairy Sci 1991;74:3583-97. https://doi.org/10.3168/jds.S0022-0302(91)78551-2

18. Porter MG, Murray RS. The volatility of components of grass silage on oven drying and the inter-relationship between drymatter content estimated by different analytical methods. Grass Forage Sci 2001;56:405-11. https://doi.org/10.1046/j. 1365-2494.2001.00292.x

19. Choct M, Hughes RJ, Wang J, Bedford MR, Morgan AJ, Annison $\mathrm{G}$. Increased small intestinal fermentation is partly responsible for the anti-nutritive activity of non-starch polysaccharides in chickens. Br Poult Sci 1996;37:609-21. https://doi.org/10. 
1080/00071669608417891

20. Wilfart A, Montagne L, Simmins PH, van Milgen J, Noblet J. Sites of nutrient digestion in growing pigs: effect of dietary fiber. J Anim Sci 2007;85:976-83. https://doi.org/10.2527/jas. 2006-431

21. Chabeauti E, Noblet J, Carre B. Digestion of plant cell walls from four different sources in growing pigs. Anim Feed Sci Technol 1991;32:207-13. https://doi.org/10.1016/0377-8401 (91)90024-M

22. Urriola PE, Stein HH. Comparative digestibility of energy and nutrients in fibrous feed ingredients fed to Meishan and Yorkshire pigs. J Anim Sci 2012;90:802-12. https://doi.org/ 10.2527/jas.2010-3254

23. Freire JPB, Guerreiro AJG, Cunha LF, Aumaitre A. Effect of dietary fibre source on total tract digestibility, caecum volatile fatty acids and digestive transit time in the weaned piglet. Anim Feed Sci Technol 2000;87:71-83. https://doi.org/10. 1016/S0377-8401(00)00183-8

24.Zhao JB, Bai Y, Tao SY, et al. Fiber-rich foods affected gut bacterial community and short-chain fatty acids production in pig model. J Funct Foods 2019;57:266-74. https://doi.org/10. 1016/j.jff.2019.04.009

25. Jørgensen H, Serena A, Hedemann MS, Bach Knudsen KE. The fermentative capacity of growing pigs and adult sows fed diets with contrasting type and level of dietary fibre. Livest
Sci 2007;109:111-4. https://doi.org/10.1016/j.livsci.2007.01. 102

26. Presto MH, Lyberg K, Lindberg JE. Effect of body weight on ileal endogenous nitrogen and amino acid loss in PVTCcannulated pigs. Livest Sci 2010;134:18-20. https://doi.org/ 10.1016/j.livsci.2010.06.084

27.Ivarsson E, Frankow-Lindberg BE, Andersson K, Lindberg JE. Growth performance, digestibility and faecal coliform bacteria in weaned piglets fed a cereal-based diet including either chicory (Cichorium intybus L) or ribwort (Plantago lanceolata L) forage. Animal 2011;5:558-64. https://doi.org/ $10.1017 /$ S1751731110002193

28. Dierick NA, Vervaeke IJ, Demeyer DI, Decuypere JA. Approach to the energetic importance of fibre digestion in pigs. 1. Importance of fermentation in the overall energy supply. Anim Feed Sci Technol 1989;23:141-67. https://doi.org/10.1016/ 0377-8401(89)90095-3

29.Le Goff G, Noblet J. Comparative total tract digestibility of dietary energy and nutrients in growing pigs and adult sows. J Anim Sci 2001;79:2418-27. https://doi.org/10.2527/2001. $7992418 \mathrm{x}$

30.Lindberg JE. Fiber effects in nutrition and gut health in pigs. J Anim Sci Biotechnol 2014;5:15. https://doi.org/10.1186/20491891-5-15 